\title{
Assessment of Radon, Radium, and Uranium Concentrations in Decorative Materials (Used to walls) Samples in Iraqi Markets
}

\author{
ALI ABID ABOJASSIM ${ }^{1 *}$, ALI SAEED JASSIM ${ }^{2}$, HOWAIDA MANSOUR AHMED ${ }^{3}$, \\ HAYDER HAMZA HUSSIAN ${ }^{1}$ \\ ${ }^{1}$ Department of Physics, Faculty of Science, University of Kufa, Al-Najaf, IRAQ \\ ${ }^{2}$ Department of Radiology Techniques, College of Medical Technology, The Islamic University, \\ Najaf, IRAQ \\ ${ }^{3}$ Department of Physics, College of Sciences and Arts, Qassim University, Qassim, SAUDI ARABIA
}

\begin{abstract}
In present study, natural alpha emitters $\left({ }^{222} \mathrm{Rn},{ }^{226} \mathrm{Ra}\right.$, and $\left.{ }^{238} \mathrm{U}\right)$ were tested in decorative materials used as walls collected from different Iraqi local markets by CR-39 detectors that it was purchased from TASTRAK Analysis System. Annual effective dose and radon exhalation rate were calculated. The results obtained showed that the range and average value of ${ }^{222} \mathrm{Rn}$ concentrations in air container were $7.94-738.10$ $\mathrm{Bq} / \mathrm{m}^{3}$ and $252.38 \pm 37.63 \mathrm{~Bq} / \mathrm{m}^{3}$, while ${ }^{222} \mathrm{Rn}$ concentrations in in sample were $45.73-4252.99 \mathrm{~Bq} / \mathrm{m}^{3}$ and $1454.25 \pm 216.84 \mathrm{~Bq} / \mathrm{m}^{3}$. The ranged of ${ }^{226} \mathrm{Ra}$ and ${ }^{238} \mathrm{U}$ concentrations were $0.010-1.000 \mathrm{~Bq} / \mathrm{kg}$, with an average value $0.278 \pm 0.04 \mathrm{~Bq} / \mathrm{kg}$ and $0.01-1.24 \mathrm{ppm}$, with an average value $0.344 \pm 0.05 \mathrm{ppm}$, respectively. The results obtained showed that the range and average value of annual effective dose in $\mathrm{mSv} / \mathrm{y}$ were $0.2-18.62$ and $6.29 \pm 0.95$. Also, it is found that the mass exhalation rate as well as surface exhalation rate were $8.38 \pm 1.33$ $\mathrm{mBq} / \mathrm{kg}$.day and $240.77 \pm 36.56 \mathrm{mBq} / \mathrm{m}^{2}$.day, respectively. The data of ${ }^{222} \mathrm{Rn}$ concentration (in air container), and annual effective dose in some samples of the present study were higher than the global limit range (200$\left.300 \mathrm{~Bq} / \mathrm{m}^{3}\right)$, and $(3-10 \mathrm{mSv} / \mathrm{y})$ according to ICRP. While, all results of ${ }^{226} \mathrm{Ra}$, and ${ }^{238} \mathrm{U}$ concentrations as well as the mass with surface exhalation rate were within the permissible limits that suggested by UNSEAR, and ICRP. Then, it can be concluded that the most samples of decorative materials which used as walls according to radiation scope no causes health risk.
\end{abstract}

Key-Words: - Alpha emitters, decorative materials, building materials, and CR-39 detectors.

Received: May 10, 2021. Revised: October 18, 2021. Accepted: November 15, 2021. Published: December 2, 2021.

\section{Introduction}

Human exposure to ionizing radiation is the most important subject that tends to public attention. Natural radiation is responsible for the total radiation exposure of the human population [1]. A large part of all exposure for most people is natural radiation of exposure, possibly forming a baseline upon and man-made source. The dose of natural radioactivity is very important to discuss in both ways: it affects health and the percentage of manmade radiation because natural radiation is the main source of exposure for humans. There are naturally occurring radionuclides materials (NORMS) that can be present in rocks and soils, For example, ${ }^{238} \mathrm{U}$ and ${ }^{232} \mathrm{Th}$ which are radionuclides, and ${ }^{40} \mathrm{~K}$ which is originated in the primordial era [2]. These materials are still more than billions of years in the soils and rocks, so that simply can be called permanent. Furthermore, the cosmic radiation, internal radiation, and building materials contained NORMS, which are the main source of exposure
[3]. These materials can be studied and tend to determine the amount of public by estimate the natural radioactivity. There is no way to avoid being exposed to these natural sources, which, in fact, cause most of the radiation exposure of the world's population. The global average effective dose per person is about $2.4 \mathrm{mSv}$ and ranges from about 1 to more than $10 \mathrm{mSv}$ depending on where people live [1]. Buildings may trap a particular radioactive gas, called radon, or the building material itself may contain radionuclides that increase radiation exposure. Radon is a rare natural element as it is found in gas form, noble and radioactive in its isotopes. Radon gas can be gathered in buildings, especially in closed regions, such as under roofs and basement. It is found in some spring waters and hot springs too [4]. Radon gas may be a problem for human health. The presence of ${ }^{226} \mathrm{Ra}$ in the ground of the facilities and the building materials is considered the main radon source of radon [3]. The outside air also has a role in radon concentration 
indoors, through the air ventilation. It was noticed that high indoor radon levels are created from radon that is in the underlying rocks and soils [5]. However, once it percolates into an enclosed space, such as a building, it can accumulate to dangerous levels, depending on the concentration of radon in the underlying soil and the construction details of the building. Both building and decorative materials contain a little number of alpha emitters (such as Uranium-238, Radium-226, and Radon-222) are mostly damaging if they are ingested or inhaled into the lungs. These building materials have a high level of natural radionuclides those results from a huge dose inside than outside. Moreover, public radiation possibly increases, if people live in buildings constructed or their houses. This increase in radiation may because using the materials that already have radiation doses more than normal levels in the area. For example: using red clay, flyash, rock, soil, sand, and other building materials $[6,7]$. The radon emissions from building materials are important to consider in certain cases. For other building materials, the emission of radon can be prevented by the selection of materials with low radium concentrations [6]. Iraq has no guidelines prescribing or standard levels of radioactivity in decorative building materials to be acceptable in our country. There are many ranges of building materials used for indoor and outdoor decoration purposes. Some studies are using CR-39 detectors to investigate decorative materials [7-9]. This study aims to establish measurements for natural alpha emitters (such as Uranium-238, Radium-226, and Radon-222) concentration in the decorative materials used as walls in Iraqi buildings. In the present study, measurements of alpha emitters were carried out for decorative materials using the TASLIMAGE System with CR-39 detectors.

\section{Materials and Methods}

\subsection{Collection of the Samples}

Thirty kinds of decorative materials samples that comment used for walls by Iraqi building during November 2020 from different locations of Iraqi markets. Decorative materials are divided into categories based on their intended use such as walls, floors, ceilings, and roofs. In the present study, exterior and interior of walls samples were collected which written according to name, type of samples, and origin of samples, as shown in Table (1).

Table 1. Information about the decorative materials samples used to walls that available in Iraqi markets and made from different countries.

\begin{tabular}{|c|c|c|c|c|c|c|c|c|c|}
\hline$\dot{\mathbf{z}}$ & 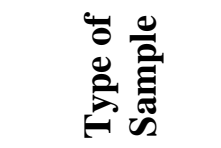 & 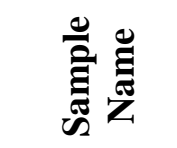 & Uू & 竞 & $\dot{\mathbf{Z}}$ & 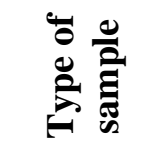 & 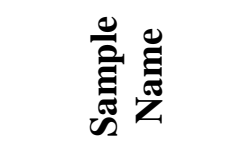 & Uू & ס \\
\hline 1 & White Cement & Saten & W1 & Germany & 16 & Rock & Camelot & W16 & Iran \\
\hline 2 & White Cement & Turbo & W2 & Germany & 17 & Rock & Adlit & W17 & Iran \\
\hline 3 & White Cement & Fuga & W3 & Germany & 18 & Rock & Tabco & W18 & Jordon \\
\hline 4 & White Cement & Tchno & W4 & Bulgaria & 19 & Alabaster & AMB & W19 & Iran \\
\hline 5 & White Cement & Almalij & W5 & Iraq & 20 & Alabaster & Merdo & W20 & Turkey \\
\hline 6 & Rock & Isfahan & W6 & Iran & 21 & Alabaster & Yunfu & W21 & Iran \\
\hline 7 & White Cement & Darsaan & W7 & Iran & 22 & Alabaster & ECF & W22 & Turkey \\
\hline 8 & Mirror (2mm) & Iranglassco & W8 & China & 23 & Rock & Berdan Kazemi & W23 & Iran \\
\hline 9 & Mirror (4mm) & Iranglassco & W9 & Iran & 24 & Rock & Iran zamil & W24 & Iran \\
\hline 10 & Mirror (4mm) & Sinoy & W10 & China & 25 & Cement & Benoid & W25 & Iran \\
\hline 11 & Rock & Volcavo & W11 & Brazil & 26 & Cement & Cimsa & W26 & Turkey \\
\hline 12 & Rock & Wand & W12 & Iran & 27 & Cement & Shargh & W27 & Iran \\
\hline 13 & Rock & Belcar & W13 & Spain & 28 & Cement & Cement & W28 & Iran \\
\hline 14 & White Cement & Almaein & W14 & Iran & 29 & Rock & Hans & W29 & China \\
\hline 15 & Rock & Tratonen & W15 & Iran & 30 & Cement & Ferana & W30 & Turkey \\
\hline
\end{tabular}

\subsection{Preparation of the Samples}

After the collection of decorative materials samples, all samples are packed in polyethylene bags, and transferred to the laboratory in the physics department, Faculty of Science, University of Kufa. Samples were prepared for measuring by drying and placed by $6 \mathrm{hr}$ at $100{ }^{\circ} \mathrm{C}$ in the oven. Next, using a mill model FT102 supplied by 
TAISITE to crush all samples and reach a suitable homogeneity. Then, the samples were filtered through a $0.8 \mathrm{~mm}$ pore size diameter. The weight of the respective net is measured and recorded with a high sensitive digital weighing balance $( \pm 0.01 \%)$. The specific activity of sample is defined as its activity per unit mass, so used the high sensitive digital weighing balance for getting the very high accuracy security of the specific activity radon, radium, and uranium. About $70 \mathrm{gm}$ packed in a standard container (radius $2.75 \mathrm{~cm}$, and length 11.5 $\mathrm{cm})$ which is sealed and dry weighed. Finally, samples were kept for a couple of 4 weeks before measuring to recorded the secular equilibrium between ${ }^{222} \mathrm{Rn}$ and ${ }^{226} \mathrm{Ra}[10]$.

\subsection{Measurement Methods of the Samples}

Poly allyldiglycol carbonate (PADC) plastic, also known as CR-39 $\left(\mathrm{C}_{12} \mathrm{H}_{18} \mathrm{O}_{7}\right)$, serves as a solid-state nuclear track detector which is highly sensitive to a particles. It is manufactured by Track Analysis Systems Ltd. at Bristol University under the trade name TASTRAK. Alpha-particle detection with TASTRAK carried out in this laboratory provides spectroscopic information. The shape and dimensions of $\alpha$-particle tracks are measured, either manually or by automated image analysis, and these measurements are used to derive for each track the dip angle and range in the plastic. CR-39 detector was used in present study that produced from TASTRAK company (Ltd., UK: TASTRACK) and developed by TASL. These detectors have many properties such as density $\left(1.32 \mathrm{~g} / \mathrm{cm}^{3}\right)$, thickness $(1 \mathrm{~mm})$, dimensions $(2.5 \mathrm{~cm} \times 2.5 \mathrm{~cm})$, and each detector has special code and number to fit TASL image system. After end the time secular equilibrium, radon concentrations were measured for decorative materials samples are placed in the bottom of this tube then, CR-39 detector was installed by adhesive tape at the bottom of tube cover, then stored for 90 days (the exposure time) to ensure the radionuclide that exist in the samples reach equilibrium state. To prevent radon gas from escaping out, the containers' covers were fastened with a layer of adhesive tape. The current investigation used a long-term irradiation approach. After the irradiation period has ended, the detectors are removed from the containers and the chemical etching procedure begins. Next 90 day, CR-39 detectors were placed in a solution of $\mathrm{NaOH}$ at $6.25 \mathrm{~N}$ and temperature at $85^{\circ} \mathrm{C}$ within 3 hours [11]. Then, detectors have been removed from the solution and extensively washed by a distilled water, and dried by soft tissue papers. At last, a microscopic treatment was performed to calculate of track density $(\rho)$ in unit Track $/ \mathrm{mm}^{2}$ by TASLIMAGE system which determined track density by automatically [12]. The TASLIMAGE is a track analysis device based on a microscope that uses high quality Nikon optics to accomplish remarkable track and background feature discrimination. The technology is one-of-akind in that it analyzes and classifies any single track before calculating the dosage. The algorithm that distinguishes an etched track from a background feature, whether it's a scratch, a hair, or anything else, does so by analyzing 31 distinct criteria related to track characteristics. The method might be used in research as a totally automated readout system or for single plastic analysis. To create a dosage measurement for any slice of plastic in the automated mode, that is generally used for dosimetry services, simply a single click is required Individual plastics can also be analyzed using a user interface that offers a variety of choices for in-depth research. The scan data is translated to a dosage measurement automatically, and the findings are stored in a database. The system can read "Auto scan" type plastics or be adapted for any size plastic, including automated ID scanning, in addition to our own unique TASTRAK format detectors.

\subsection{Calculations}

\subsection{1 ${ }^{222} \mathrm{Rn},{ }^{226} \mathrm{Ra}$, and ${ }^{238} \mathrm{U}$ concentrations}

${ }^{222} \mathrm{Rn}$ concentrations in the airspace of container $(\mathrm{C})$ in $\mathrm{Bq} / \mathrm{m}^{3}$ was calculated by [13]:

$$
C\left(\frac{\mathrm{Bq}}{\mathrm{m}^{3}}\right)=\frac{\rho}{\mathrm{K} \mathrm{t}}
$$

where, $\quad \mathrm{K}$ is the calibration factor of the CR-89 detector which calibrated using $\left({ }^{222} \mathrm{Rn}\right.$ source $){ }^{226} \mathrm{Ra}$ source $\left(\boldsymbol{A}_{\mathbf{2 2 6}_{R a}}=6600 \mathrm{~Bq}\right) .{ }^{222} \mathrm{Rn}$ activity $\left(\boldsymbol{A}_{\mathbf{2 2 2}}{ }_{R n}\right)$ in $\mathrm{Bq}$ was calculated according to ${ }^{226} \mathrm{Ra}$ activity by equation (2) [14]:

$$
A_{222_{R n}}(B q)=A_{226_{R a}}\left(1-e^{-\lambda t}\right)
$$

Where, $\lambda$ is decays constant for ${ }^{222} \mathrm{Rn}$, and $\mathrm{t}$ is irradiation time in day which used the present study was $0.5,1,1.5,2,2.5$, and 3 day.

The radon exposure $\left(E_{R n}\right)$ in cylindrical container (volume V) can be determined by [15]:

$$
\begin{aligned}
& E_{R n}\left(\text { Bq.day.m } m^{-3}\right)=\left[A_{222_{R n}}(B q) / V\left(m^{3}\right)\right] * \\
& t \text { (day) }
\end{aligned}
$$


Slope of curve (calibration factor) was calculated using the relation between $\mathrm{E}_{\mathrm{Rn}}$ (at different irradiation time $0.5,1,1.5,2,2.5$, and 3 day) and $\rho$ (track density in CR-39 detectors that corresponding to irradiation time), which equal, as follows:

$$
\text { Slope }=\frac{\rho}{E_{R n}}
$$

At last, the calibration factor in present study was $(0.28 \pm 0.043)$ Track.cm $^{-2} /$ Bq. $\mathrm{m}^{-3}$.day which it was similarity or nearly for previous studies that reported by [16-22].

${ }^{222} \mathrm{Rn}$ concentration $\left(\mathrm{C}_{\mathrm{Rn}}\right)$ in sample according to $\mathrm{C}$ $\left({ }^{222} \mathrm{Rn}\right.$ in airspace), $\lambda\left({ }^{222} \mathrm{Rn}\right.$ decay constant), $\mathrm{h}$ (thickness of the sample which equal $3 \mathrm{~cm}$ ), and $\mathrm{L}$ (distance between sample to detector which equal $8.5 \mathrm{~cm})$, as following [23, 24]

$$
C_{R_{n}}\left(\frac{B q}{m^{3}}\right)=C\left(\frac{\lambda h t}{L}\right)
$$

${ }^{226} \mathrm{Ra}$ activity content in the sample $\left(\mathrm{C}_{\mathrm{Ra}}\right)$ in $\mathrm{Bq} / \mathrm{kg}$ was calculated by equation (6) [25] which depend on many parameters such as $\rho$ (track density), $h$ (thickness of the sample which equal $3 \mathrm{~cm}$ ), A (area of container), $\mathrm{M}$ (mass of sample in $\mathrm{kg}$ ), $\mathrm{k}$ (calibration factor of track detector), and $\mathrm{T}_{\text {eff }}$ (time of actual exposure) which can be determined by following [26]

$$
C_{R a}\left(B q \cdot K g^{-1}\right)=\left(\frac{\rho}{k \cdot T_{e f f}}\right)\left(\frac{h A}{M}\right)
$$

$\mathrm{T}_{\text {eff }}$ was calculated using equation (7), as following [26]

$$
T_{e f f}=\left[T-\lambda_{R n}^{-1}\left(1-e^{-\lambda_{R n} T}\right)\right]
$$

${ }^{238} \mathrm{U}$ concentrations of uranium $\left(\mathrm{C}_{\mathrm{U}}\right)$ in ppm was calculated using equation (8) [27], which depend on $\mathrm{W}_{\mathrm{U}}$ (weight of uranium in samples), and $\mathrm{W}_{\mathrm{S}}$ (weight of sample).

$$
C_{U}(p p m)=\frac{W_{U}}{W_{S}}
$$

Weight of uranium in samples was calculated according to the number of uranium $\left({ }^{238} \mathrm{U}\right)$ atoms in the sample. The number of uranium in sample was determined using the property of the secular equilibrium between ${ }^{222} \mathrm{Rn}$ and ${ }^{238} \mathrm{U}$.

\subsubsection{Radiological Risk}

Annual effective dose (AED) based on ${ }^{222} \mathrm{Rn}$ concentrations for decorative materials samples which depend on many parameters such as $\mathrm{C}\left({ }^{222} \mathrm{Rn}\right.$ in airspace), $\mathrm{F}$ (the equilibrium factor that equal 0.4 ), $\mathrm{H}$ (occupancy factor that equal 0.8 ), $\mathrm{T}$ (time in hours that equal $8760 \mathrm{~h} / \mathrm{y}$ ), and $\mathrm{D}$ (dose conversion factor that equal $9 \times 10^{-6} \mathrm{mSv} /$ Bq.h.m $\mathrm{m}^{-3}$ ) can be calculated by $[28,29]$.

$$
A E D\left(\frac{m S v}{y}\right)=C \times F \times H \times T \times D
$$

There is considerable public concern about radon exhalation from building materials, especially those used for interior decoration like ceramic tile which considered as an important source that contributes to indoor radon concentration through exhalation from walls and floors. Exhalation rate from decorative materials is another potential source of radon in the indoor environment. Mass and surface exhalation rate $\left(\mathrm{E}_{\mathrm{M}}\right)$ and $\left(E_{\mathrm{A}}\right)$ of the samples based on $\mathrm{C}\left({ }^{222} \mathrm{Rn}\right.$ in airspace) with another parameters were calculated using equations (10), and (11), respectively [30].

$$
\begin{aligned}
& E_{M}=\frac{C V \lambda}{M_{\text {eff }}} \\
& E_{S}=\frac{C V \lambda}{\mathrm{AT}_{\text {eff }}}
\end{aligned}
$$

\section{Results and Discussion}

Results of alpha emitters $\left({ }^{222} \mathrm{Rn},{ }^{226} \mathrm{Ra}\right.$, and $\left.{ }^{238} \mathrm{U}\right)$ in decorative materials that used as walls shown in Table (2). From Table (2), it is found that the values of $\mathrm{C}$ were ranged from $7.94 \mathrm{~Bq} / \mathrm{m}^{3}$ to $738.10 \mathrm{~Bq} / \mathrm{m}^{3}$, with an average $252.38 \pm 37.63$ $\mathrm{Bq} / \mathrm{m}^{3}$, the values of $\mathrm{C}_{\mathrm{Rn}}$ were ranged from 45.73 $\mathrm{Bq} / \mathrm{m}^{3}$ to $4252.99 \mathrm{~Bq} / \mathrm{m}^{3}$, with an average $1454.25 \pm 216.84 \mathrm{~Bq} / \mathrm{m}^{3}$, the values of $\mathrm{C}_{\mathrm{Ra}}$ were ranged from $0.010 \mathrm{~Bq} / \mathrm{kg}$ to $1.000 \mathrm{~Bq} / \mathrm{kg}$, with an average $0.278 \pm 0.04 \mathrm{~Bq} / \mathrm{kg}$, and the values of $\mathrm{C}_{\mathrm{U}}$ were ranged from $0.01 \mathrm{ppm}$ to $1.24 \mathrm{ppm}$, with an average $0.344 \pm 0.05 \mathrm{ppm}$. The higher concentrations of radon in airspace container as well as radon in sample are recorded for samples W30 (decorative cement, name Ferana, and made in Turkey), while the lowest can be observed for the samples W26 (decorative cement, name Cimsa, and made in Turkey). Also, The higher and lower of radium content as well as concentrations of uranium were recorded for samples W30 (decorative cement, name Ferana, and made in 
Turkey), and for the samples W26 (decorative cement, name Cimsa, and made in Turkey), respectively. The main reason for large differences in alpha emitters for the sample (decorative materials) seems to be due to the type of natural materials that origin samples based on the geological formation and abundant radioactive element under concentration for these materials. There are no obvious guidelines and regulations for decorative materials alpha emitters in Iraq and the world, while found in indoor air, soil, and building materials. From the radiological protection point of view, the health and environmental protection agencies have recommended a safe limit of radon indoor air for human beings. The International Commission on Radiological Protection(ICRP) has proposed that the range allowed maximum contamination level for radon concentration indoor air is $200-300 \mathrm{~Bq} / \mathrm{m}^{3}$ [30]. As well, the world average soil radon concentration suggested by many studies is $7400 \mathrm{~Bq} / \mathrm{m}^{3}[31,32]$. It is noticed that from data (Table 2) ${ }^{222} \mathrm{Rn}$ concentrations (C) indoor air due to decorative materials that used as walls were within those proposed by international organizations since the higher value $\left(300 \mathrm{~Bq} / \mathrm{m}^{3}\right)$, except some samples (W2, W3, W9, W14, W15, W16, W21, W29, and W30), while ${ }^{222} \mathrm{Rn}$ concentrations $\left(\mathrm{C}_{\mathrm{Rn}}\right)$ in all samples (decorative materials) were lower than the safe limit (7400 $\mathrm{Bq} / \mathrm{m}^{3}$ ) recommended by ICRP. Also, it is noticed that from data (Table 2) the values of radium content $\left(\mathrm{C}_{\mathrm{Ra}}\right)$ and uranium concentrations $\left(\mathrm{C}_{\mathrm{U}}\right)$ in all samples of the present study (decorative materials) were less than the level permissible limit of $\mathrm{C}_{\mathrm{Ra}}(35 \mathrm{~Bq} / \mathrm{kg})$ [34], and $\mathrm{C}_{\mathrm{U}}(11 \mathrm{ppm})$ [35] which were recommended by UNSCEAR 2000 and 1994, respectively. The results of annual effective dose (AED), mass and surface exhalation rate $\left(E_{M}\right)$, and $\left(E_{S}\right)$ of the samples based on ${ }^{222} \mathrm{Rn}$ concentrations in the airspace of the container are presented in table (3). The results of AED were ranged between $0.20 \mathrm{mSv} / \mathrm{y}$ in sample code $\mathrm{W} 26$ to 18.62 in sample code W30, with an average value of $6.29 \pm 0.95 \mathrm{mSv} / \mathrm{y}$. It can be found from the results of AED in samples of decorative materials, most samples were less than the acceptable levels of (3-10) $\mathrm{mSv} / \mathrm{y}$ which was recommended by(ICRP) [36], except samples W3. W9, W14, W15, W16, W21, W29, and W30 were higher than acceptable levels. Figure (1) shows the comparing percentage of AED between samples under study and maximum acceptable level that recommended by ICRP 1993. From figure (1), it is found that the values of percentage of samples W3 (6\%), W9(6\%), W15(7\%), W16(8\%), W21(8\%), $\mathrm{W} 29(9 \%)$, and $\mathrm{W} 30(9 \%)$ were larger than the parentage value of acceptable levels (5\%) recommended by(ICRP). The results of $E_{M}$ in-unit $\mathrm{mBq} / \mathrm{kg} . \mathrm{h}$ (Table 3) were ranged from 0.29 to 30.24 , with an average value of $8.38 \pm 1.33$, while The results of $E_{S}$ in-unit $\mathrm{mBq} / \mathrm{m}^{2}$.h were ranged from 7.67 to 713.13 , with an average value of $240.77 \pm 36.56$. While the values of $E_{S}$ (surface exhalation rate of ${ }^{222} \mathrm{Rn}$ concentrations) in all samples of the present study was much lower than the world average of $\left(57.6 \mathrm{~Bq} / \mathrm{m}^{2} . \mathrm{h}\right)$ [34]. Table (4). The average value of $\mathrm{C}$ and AED in decorative materials of the present study at different origin countries were shown in table (4). it can be seen that, the higher average value of $\mathrm{C}$ was 315.76 $\mathrm{Bq} / \mathrm{m}^{3}$ for decorative materials that made in Iran, while the lower was $79.37 \mathrm{~Bq} / \mathrm{m}^{3}$ for decorative materials that made in Brazil. Also from table (4), the higher average value of AED was $7.81 \mathrm{mSv} / \mathrm{y}$ for decorative materials that made in Germany, while the lower was $2 \mathrm{mSv} / \mathrm{y}$ for decorative materials that made in Brazil. The average value of $\mathrm{C}$ and AED in different types of decorative materials in present study were shown in table (5). it can be seen that, the higher average value of $\mathrm{C}$ was $296.032 \mathrm{~Bq} / \mathrm{m}^{3}$ for decorative materials type of decorative cement, while the lower was 201.27 $\mathrm{Bq} / \mathrm{m}^{3}$ for decorative materials type decorative white cement. Also from table (5), the higher average value of AED was $7.47 \mathrm{mSv} / \mathrm{y}$ for decorative materials type cement, while the lower was $5.09 \mathrm{mSv} / \mathrm{y}$ for decorative materials type white cement. These variation depending on the type of raw materials used in the manufacture of each one. But the average value of $\mathrm{C}$ and AED in all courtiers were lower than the world average limit, except some samples have high ${ }^{222} \mathrm{Rn}$ concentrations that shown above which may be due to the kind and nature of soil as well as natural materials from which the cement is manufactured. Finally and according to light of the study, it can be shown that the data obtained in this study improve the suitability of the CR-39 detector technique for such complex samples.

Table 2. Results of alpha emitters in decorative materials (walls).

\begin{tabular}{|c|c|c|c|c|c|}
\hline No. & Sample code & $\mathbf{C}\left(\mathbf{B q} / \mathbf{m}^{\mathbf{3}}\right)$ & $\mathbf{C}_{\mathbf{R n}}\left(\mathbf{B q} / \mathbf{m}^{\mathbf{3}}\right)$ & $\mathbf{C}_{\mathbf{R a}}(\mathbf{B q} / \mathbf{k g})$ & $\mathbf{C}_{\mathbf{U}}(\mathbf{p p m})$ \\
\hline 1 & $\mathrm{~W} 1$ & 91.27 & 525.91 & 0.092 & 0.11 \\
\hline 2 & $\mathrm{~W} 2$ & 333.33 & 1920.71 & 0.506 & 0.63 \\
\hline
\end{tabular}




\begin{tabular}{|c|c|c|c|c|c|}
\hline 3 & W3 & 503.97 & 2903.92 & 0.683 & 0.84 \\
\hline 4 & W4 & 111.11 & 640.24 & 0.187 & 0.23 \\
\hline 5 & W5 & 95.24 & 548.77 & 0.131 & 0.16 \\
\hline 6 & W6 & 253.97 & 1463.39 & 0.250 & 0.31 \\
\hline 7 & W7 & 75.40 & 434.45 & 0.108 & 0.13 \\
\hline 8 & W8 & 182.54 & 1051.82 & 0.156 & 0.19 \\
\hline 9 & W9 & 527.78 & 3041.12 & 0.477 & 0.59 \\
\hline 10 & W10 & 103.17 & 594.50 & 0.106 & 0.13 \\
\hline 11 & W11 & 79.37 & 457.31 & 0.091 & 0.11 \\
\hline 12 & W12 & 11.90 & 68.60 & 0.013 & 0.02 \\
\hline 13 & W13 & 107.14 & 617.37 & 0.110 & 0.14 \\
\hline 14 & W14 & 424.60 & 2446.61 & 0.671 & 0.83 \\
\hline 15 & W15 & 543.65 & 3132.58 & 0.421 & 0.52 \\
\hline 16 & W16 & 619.05 & 3567.03 & 0.652 & 0.81 \\
\hline 17 & W17 & 103.17 & 594.50 & 0.126 & 0.16 \\
\hline 18 & W18 & 83.33 & 480.18 & 0.075 & 0.09 \\
\hline 19 & W19 & 218.25 & 1257.61 & 0.200 & 0.25 \\
\hline 20 & W20 & 186.51 & 1074.68 & 0.134 & 0.17 \\
\hline 21 & W21 & 623.02 & 3589.89 & 0.577 & 0.71 \\
\hline 22 & W22 & 134.92 & 777.43 & 0.123 & 0.15 \\
\hline 23 & W23 & 39.68 & 228.66 & 0.037 & 0.05 \\
\hline 24 & W24 & 115.08 & 663.10 & 0.103 & 0.13 \\
\hline 25 & W25 & 246.03 & 1417.66 & 0.263 & 0.33 \\
\hline 26 & W26 & 7.94 & 45.73 & 0.010 & 0.01 \\
\hline 27 & W27 & 265.87 & 1531.99 & 0.284 & 0.35 \\
\hline 28 & W28 & 222.22 & 1280.47 & 0.296 & 0.37 \\
\hline 29 & W29 & 523.81 & 3018.25 & 0.457 & 0.56 \\
\hline 30 & W30 & 738.10 & 4252.99 & 1.000 & 1.24 \\
\hline \multicolumn{2}{|c|}{ Average \pm S.E } & $252.38 \pm 37.63$ & $1454.25 \pm 216.84$ & $0.278 \pm 0.04$ & $0.344 \pm 0.05$ \\
\hline
\end{tabular}

Table 3. Results of AED, $\mathrm{E}_{\mathrm{M}}$, and $\mathrm{E}_{\mathrm{S}}$ in decorative materials (walls).

\begin{tabular}{|c|c|c|c|c|}
\hline No. & Sample code & AED (mSv/y) & $\mathrm{E}_{M}(\mathrm{mBq} / \mathrm{kg} . \mathrm{h})$ & $E_{S}\left(m B q / m^{2} . h\right)$ \\
\hline 1 & $\mathrm{~W} 1$ & 2.30 & 2.79 & 88.18 \\
\hline 2 & W2 & 8.41 & 15.30 & 322.06 \\
\hline 3 & W3 & 12.71 & 20.65 & 486.92 \\
\hline 4 & W4 & 2.80 & 5.66 & 107.35 \\
\hline 5 & W5 & 2.40 & 3.97 & 92.02 \\
\hline 6 & W6 & 6.41 & 7.57 & 245.38 \\
\hline 7 & W7 & 1.90 & 3.26 & 72.85 \\
\hline 8 & W8 & 4.61 & 4.71 & 176.37 \\
\hline 9 & W9 & 13.32 & 14.42 & 509.93 \\
\hline 10 & W10 & 2.60 & 3.20 & 99.69 \\
\hline 11 & W11 & 2.00 & 2.76 & 76.68 \\
\hline 12 & W12 & 0.30 & 0.40 & 11.50 \\
\hline 13 & W13 & 2.70 & 3.32 & 103.52 \\
\hline 14 & W14 & 10.71 & 20.30 & 410.24 \\
\hline 15 & W15 & 13.72 & 12.73 & 525.26 \\
\hline 16 & W16 & 15.62 & 19.73 & 598.11 \\
\hline 17 & W17 & 2.60 & 3.82 & 99.69 \\
\hline 18 & W18 & 2.60 & 3.82 & 99.69 \\
\hline 19 & W19 & 2.60 & 3.82 & 99.69 \\
\hline 20 & W20 & 4.71 & 4.04 & 180.20 \\
\hline 21 & W21 & 15.72 & 17.43 & 601.95 \\
\hline 22 & W22 & 3.40 & 3.73 & 130.36 \\
\hline 23 & W23 & 1.00 & 1.11 & 38.34 \\
\hline 24 & W24 & 2.90 & 3.11 & 111.19 \\
\hline 25 & W25 & 6.21 & 7.95 & 237.71 \\
\hline 26 & W26 & 0.20 & 0.29 & 7.67 \\
\hline
\end{tabular}




\begin{tabular}{|c|c|c|c|c|}
\hline 27 & W27 & 6.71 & 8.59 & 256.88 \\
\hline 28 & W28 & 5.61 & 8.94 & 214.71 \\
\hline 29 & W29 & 13.22 & 13.81 & 506.09 \\
\hline 30 & W30 & 18.62 & 30.24 & 713.13 \\
\hline \multicolumn{2}{|c|}{ Average \pm S.E } & $6.29 \pm 0.95$ & $8.38 \pm 1.33$ & $240.77 \pm 36.56$ \\
\hline
\end{tabular}

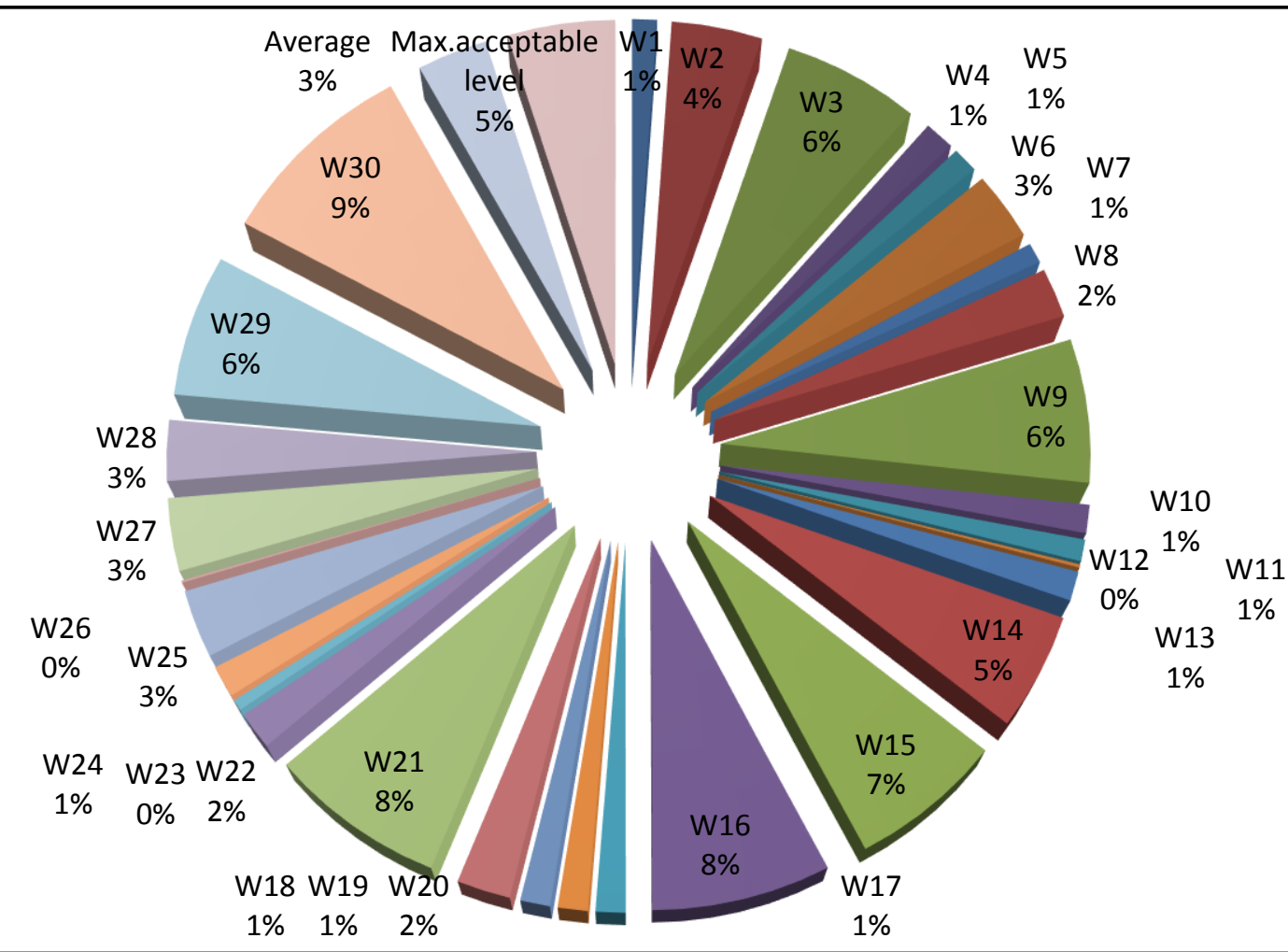

Fig. 1: The comparing percentage of AED between samples under study and maximum acceptable level that recommended by ICRP 1993.

Table 4. The comparing of $\mathrm{C}$ and AED in decorative materials at different origin countries.

\begin{tabular}{|c|c|c|c|}
\hline No. & Origin Country & $\mathbf{C}\left(\mathbf{B q} / \mathbf{m}^{\mathbf{3}}\right)$ & $\mathbf{A E D}(\mathbf{m S v} / \mathbf{y})$ \\
\hline 1 & Germany & 309.52 & 7.81 \\
\hline 2 & Bulgaria & 111.11 & 2.8 \\
\hline 3 & Iran & 315.76 & 7.76 \\
\hline 4 & China & 269.84 & 6.81 \\
\hline 5 & Brazil & 79.37 & 2 \\
\hline 6 & Spain & 107.14 & 2.7 \\
\hline 7 & Jordanian & 83.33 & 2.6 \\
\hline 8 & Turkey & 266.87 & 6.73 \\
\hline 9 & Iraq & 95.24 & 2.4 \\
\hline
\end{tabular}

Table 5. The comparing of $\mathrm{C}$ and AED in different types of decorative materials in present study.

\begin{tabular}{|c|c|c|c|}
\hline No. & Type of decorative material & $\mathbf{C}\left(\mathbf{B q} / \mathbf{m}^{\mathbf{3}}\right)$ & $\mathbf{A E D}(\mathbf{m S v} / \mathbf{y})$ \\
\hline 1 & White cement & 201.72 & 5.09 \\
\hline 2 & Rock & 225.47 & 5.73 \\
\hline 3 & Mirror & 271.16 & 6.84 \\
\hline 4 & Alabaster & 290.675 & 6.61 \\
\hline 5 & Cement & 296.032 & 7.47 \\
\hline
\end{tabular}




\section{Conclusion}

The decorative materials in the present study are found to contain natural alpha emitters at different rates according to origin countries and types of decorative materials. Therefore, it can be concluded that the results of ${ }^{222} \mathrm{Rn}$ concentrations in samples, ${ }^{226} \mathrm{Ra}$ activity content and concentrations of uranium, as well as mass and surface exhalation rate of the thirty kinds of decorative materials samples that comment used for walls by Iraqi building in the present study, were lower than the acceptable of the permissible limit. While radon concentrations in air space of the container and annual effective dose for some samples such as W3. W9, W14, W15, W16, W21, W29, and W30 were greater than the acceptance of the permissible limit. Accordingly, It should be careful in using it as decorative materials.

\section{References:}

[1] Berg, H. C. (2006). Biological and Medical Physics, biomedical engineering Second Edition. Tennessee, USA ., 1-745.

[2] L'Annunziata, M. F. (2007). Introduction: radioactivity and our well- being. Radioactivity, 1-45.

[3] Rich S. E., Dharmarajan K. V. (2012). Introduction to Radiation, The Canadian Nuclear Safety Commission., 1-38.

[4] Shultis, J. K., \& Faw, R. E. (2002). Fundamentals of nuclear science and engineering. New york 10016 , Basel.

[5] Martin, J. E. (2013). Physics for radiation protection. Germany: Wiley., 270-279

[6] Swallow, A. J. (2016). Radiation Chemistry of Organic Compounds: International Series of Monographs on Radiation Effects in Materials (Vol. 2). Elsevier.

[7] Tchorz-Trzeciakiewicz, D. E., \& Olszewski, S. R. (2019). Radiation in different types of building, human health. Science of The Total Environment, 667, 511-521.

[8] Čeliković, I. T., Pantelić, G. K., Živanović, M. Z., Vukanac, I. S., Krneta Nikolić, J. D., Kandić, A. B., \& Lončar, B. B. (2020). Radon and thoron exhalation rate measurements from building materials used in Serbia. Nukleonika, 65.

[9] Abojassim, A. A. (2021). Radiological Risk Assessment of Radon Gas in Bricks Samples in Iraq. Journal of Nuclear Engineering and Radiation Science, 7(3), 032001.

[10] Abojassim, A. A., \& Rasheed, L. H. (2021). Natural radioactivity of soil in the Baghdad governorate. Environmental

Earth

Sciences, 80(1), 1-13.

[11] TASLIMAGE dosimetry system, Track Analysis Systems Ltd,(2015), www.tasl.co.uk.

[12] Qasim, A. M. S., Hussain, H. H., \& Abojassim, A. A. (2018). Radon Concentrations and Annual Effective Dose in Cigarette Samples (Domestic and Importer) At the Iraqi Markets. Journal of Radiation and Nuclear Applications, 3(2), 83.

[13] Ibrahim, A. A., Hashim, A. K., \& Abojassim, A. A. (2021). Determination of alpha activity in soil samples of agricultural college of kerbala university, Iraq. Annals of Agri Bio Research, 26(1), 125-131.

[14] Michael, F. (2007), Radioactivity: Introduction and History, 1st edition, Elsevier.

[15] Chen, J., Rahman, N. M., \& Atiya, I. A. (2010). Radon exhalation from building materials for decorative use. Journal of environmental radioactivity, 101(4), 317-322.

[16] Khan, A. J., Varshney, A. K., Prasad, R., Tyagi, R. K., \& Ramachandran, T. V. (1990). Calibration of a CR-39 plastic track detector for the measurement of radon and its daughters in dwellings. International Journal of Radiation Applications and Instrumentation. Part D. Nuclear Tracks and Radiation Measurements, 17(4), 497-502.

[17] Grasty, R. L. (1997). Radon emanation and soil moisture effects on airborne gamma-ray measurements. Geophysics, 62(5), 1379-1385.

[18] Mohammed, E. J. Radon concentrations in some soil and air samples of dwellings in Karbala City and influencing factors on lung cancer risks using CR-39 (Doctoral dissertation, MSc Thesis (University of Kerbala College of Science, 2016)).

[19] Subber, A. R., Noori, H. N., Ali, F. N., Jabbar, H. J., \& Khodier, M. K. (2015). Constructasa simple radon chamber for measurement of radon detectors calibration factors. Pelagia research library, Advances in applied Science research, 6(2), 128-131.

[20] Abojassim, A. A. Radon and Thoron Concentrations Measurement in Al-Najaf and Al-Kufa Area (Doctoral dissertation, PHd Thesis (Baghdad University College of Science, 2013)).

[21] Salih, N. F., (2014). Impact of alpha emitters on uterus, blood, urine and hormones of infertile woman of Iraqi Kurdistan. PhD Thesis, College of Education, Universiti Sains Malaysia. 
[22] de Campos, M. P., \& Martins, E. W. (2007). Calibration of the solid state nuclear track detector CR-39 for radon measurements. Associacao Brasileira De Energia Nuclear-ABEN.

[23] Mohammad, A. I., \& Al-Zubaidy, N. N. (2012). Estimation of natural radioactivity in water and soil in some villages of irbid city. Applied physics research, 4(3), 39.

[24] Khan, M. S., Srivastava, D. S., \& Azam, A. (2012). Study of radium content and radon exhalation rates in soil samples of northern India. Environmental Earth Sciences, 67(5), 1363-1371.

[25] Hashim, A. K., \& Nayif, S. S. (2019). Determination of the Radiation of Alpha Particles in the Air of Primary School Buildings in the City of Karbala. EXECUTIVE EDITOR, 10(1), 531.

[26] Azam, A., Naqvi, A. H., \& Srivastava, D. S. (1995). Radium concentration and radon exhalation measurements using LR-115 type II plastic track detectors. Nuclear geophysics, 9(6), 653-657.

[27] Khan, M. S., Zubair, M., Verma, D., Naqvi, A. H., Azam, A., \& Bhardwaj, M. K. (2011). The study of indoor radon in the urban dwellings using plastic track detectors. Environmental Earth Sciences, 63(2), 279-282.

[28] Mowlavi, A. A., Fornasier, M. R., Binesh, A., \& De Denaro, M. (2012). Indoor radon measurement and effective dose assessment of 150 apartments in Mashhad, Iran. Environmental monitoring and assessment, 184(2), 1085-1088.

[29] Abumurad, K. M., \& Al-Omari, R. A. (2008). Indoor radon levels in irbid and health risk from internal doses. Radiation Measurements, 43, S389-S391.

[30] Abojassima, A. A., Shltake, A. R., Najam, L. A., \& Merzaa, I. R. (2017). Radiological parameters due to radon-222 in soil samples at Baghdad Governorate (Karakh), Iraq. Pak. j. sci. ind. res. Ser. A: phys. sci, 60(2), 72-8.

[31] ICRP. (1995). International Commission on Radiological Protection Statement on Radon.

[32] Gupta, P., \& Kaur, G. (2015). A Concept of AKNN Clustering in Software Engineering. International Journal of Computer Applications, 119(18).

[33] Xiaofeng, H., \& Guosheng, W. (2011). Surface radon exhalation rates of building material and soil effect on indoor air radon concentration. Procedia Engineering, 18, 122127.
[34] UNSCEAR. (2000). Sources and Effects of Ionizing Radiation, United Nations Scientific Committee on the Effects of Atomic Radiation UNSCEAR 2000 Report to the General Assembly, with Scientific Annexes,. Vol. I: sources, vol II: Effects, New York, 1-17.

[35] United Nations Scientific Committee on the Effects of Atomic Radiation. (1994). Sources and effects of ionizing radiation. UNSCEAR 1994 report to the General Assembly, with scientific annexes.

[36] against Radon, P. (1993). 222 at Home and at Work, ICRP Publ. No. 65. Ann. ICRP, 23(2), 782-785.

\section{Creative Commons Attribution License 4.0 (Attribution 4.0 International, CC BY 4.0)}

This article is published under the terms of the Creative Commons Attribution License 4.0 https://creativecommons.org/licenses/by/4.0/deed.e $\underline{\mathrm{n} \text { US }}$ 